\title{
Qualitative and Quantitative Evaluation Techniques of New Infill Designs in Historic Context
}

\section{Técnicas de evaluación cualitativa y cuantitativa de nuevos diseños de relleno en contexto histórico}

Received: October 7, 2020

Accepted: November 23, 2020

\author{
Written by: \\ Mustafa A. Gaber \\ https://orcid.org/0000-0001-6237-3847 \\ Ayten Ö. Akçay ${ }^{6}$ \\ https://orcid.org/0000-0003-3409-6621
}

\begin{abstract}
With the continuing advancement in material technology and construction techniques, architects face a greater set of options and challenges when it comes to designing in historic settings. In the meantime after the ICOMOS agreement, every country adapted the policy according to their own culture and settings, therefore every architect in their respective country started interpreting the charters, and the design review processes in their own way. Working on the new addition to historic context gave rise to familiar characteristics in design, especially in the infill designs, which is "Replication and Contrast", which in turn sparked the question, how to evaluate whether a building is properly fitting in its context with whatever approach employed. This paper aims to answer this question by conducting a literature review covering First, the qualitative evaluation approach which compromises of surveys and previsualization in order to identify the main visual properties that improve the contextual compatibility of the new designs in the historical context, and quantitative techniques focused more on the mathematical scientific cognitive results of all aspects of the architectural elements within historic settings. A comparison has been made on each result achieved and an assessment of their reliance or authenticity has been tested in order to find and bridge the gap between tangible and intangible values when judging "fit" in a historic setting. The results showed that the qualitative evaluation if followed properly it could be very promising, but it always leaves room for skepticism as the result is expected to change based on the size and the characteristics of the participants. The quantitative evaluation provided a more tangible evidence of the contextual fit in
\end{abstract}

\section{Resumen}

Con el continuo avance en la tecnología de materiales y técnicas de construcción, los arquitectos enfrentan un mayor conjunto de opciones y desafíos cuando se trata de diseñar en entornos históricos. Mientras tanto, después del acuerdo ICOMOS, cada país adaptó la política de acuerdo con su propia cultura y entorno, por lo tanto, cada arquitecto en su país respectivo comenzó a interpretar las cartas y los procesos de revisión del diseño a su manera. Trabajar en una nueva adición al contexto histórico dio lugar a características familiares en el diseño, especialmente en los diseños de relleno, que es "Replicación y Contraste", que a su vez provocó la pregunta, cómo evaluar si un edificio encaja adecuadamente en su contexto con Este trabajo tiene como objetivo responder a esta pregunta mediante la realización de una revisión de la literatura que cubre en primer lugar el enfoque de evaluación cualitativa que compromete encuestas y pre-visualización con el fin de identificar las principales propiedades visuales que mejoran la compatibilidad contextual de los nuevos diseños en el contexto histórico. contexto, y técnicas cuantitativas centradas más en los resultados cognitivos científicos matemáticos de todos los aspectos de los elementos arquitectónicos dentro de entornos históricos. Se ha realizado una comparación de cada resultado alcanzado y se ha probado una evaluación de su confianza o autenticidad para encontrar y unir la brecha entre los valores tangibles e intangibles al juzgar el "ajuste" en la historia configuración ic. Los resultados mostraron que la evaluación cualitativa, si se sigue adecuadamente, podría ser muy prometedora, pero siempre deja un margen para

\footnotetext{
${ }^{5}$ B. Arch, Research Assistant, Department of Architecture, Faculty of Architecture, Near East University, Nicosia-Cyprus.

${ }^{6}$ Assist.Prof.Dr., Department of Architecture, Faculty of Architecture, Near East Univesity, Nicosia-Cyprus.
} 


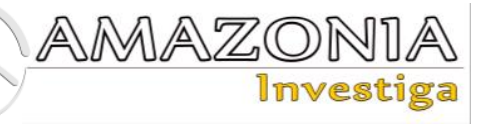

terms of architectural elements like size, proportion, and scale. Finally, a suggestion was made in order to provide a better, and a more comprehensive technique merging both methods together and trying to incorporate more of threedimensional aspects of the building instead of the two dimensionality of the current assessment techniques.

Key words: Historic Context, interpretation, new infill, qualitative evaluation, quantitative evaluation.

\section{Introduction}

Historic Sites and traditional context are an important aspect of proving past life, those places are faced with unending changes caused by historical shifts and decisive events, whether it been man-made, or natural disasters, like wars or fires that result into a quicker alteration of the existing historic fabric.

Now with the development of the field of preservation development away from architecture, preservationist are now tasked with preserving while architects are tasked with adding to those historic environments. The fields of architecture and historic preservation have remained in close symbolic relationship that is constantly evolving as advancement in one field results in adaption and recognition in the other (Skerry, 2012). The aim of adding to historic context is to help revitalize the historic context of the area, which creates a sensible and spiritual connection across the past, present and the future, as well improve the quality of urban life (Gharehbaglou, Nejadebrahimi, Ardabilchi, 2019). The notion of addition has always been enforced in architecture as stated by Bulimbašić $(2008 ; 29)$ cities are living organisms, and they can't be locked to one specific point in time. In fact one of the most vital tasks of local authorities, specifically architectural authorities is the creation of a comfortable urban environment that comprised of a harmonious combination of the old and the new in the architecture of the modern city (Mokhovikov, Alekseenko, Knyazeva, Murog, Larina, 2019).

Back then there had been a general view that new additions in historic context should aim at the replication of the existing design, appearance and materials (Skerry, 2012), and this in part due to the fact that most of the additions before the 19th century was deemed successful as it showed el escepticismo, ya que se espera que el resultado cambie según el tamaño y las características de los participantes. La evaluación cuantitativa proporcionó una evidencia más tangible del ajuste contextual en términos de elementos arquitectónicos como tamaño, proporción y escala. Finalmente se hizo una sugerencia con el fin de proporcionar una técnica mejor y más completa fusionando ambos métodos y tratando de incorporar más aspectos tridimensionales del edificio en lugar de la bidimensionalidad de las técnicas de evaluación actuales.

Palabras Clave: Contexto histórico, evaluación cualitativa, evaluación cuantitativa, interpretación, nuevo relleno.

replication of the surrounding context and material when in fact it just followed the same traditional construction techniques and materials that were available at the time, therefore, resulting in an addition that is not too distant from the surrounding context (Vozbinaite 2015;19). However, shortly after World War II, a new movement started advocating for an architecture that is not fake and "true to its time". This divided the architects into two groups; contemporary but compatible and historicized design which generally lie under Replication and contrast approaches. However each are aiming at achieving contextual compatibility (Skerry, 2012).

Over the years countries have developed their own systems of design reviews and evaluation techniques to monitor and maintain harmonious new developments in the existing context. Those regulations became more complex over time as they identified more aspects to be considered, some of them that are harder to be generalized and understood, especially when touching upon intangible features (Navickiene, 2012). In addition to this, vague terms has been interpreted differently from architect to architect, those aspects are evaluated qualitatively by performing questionnaires, survey, and observations by an appointed committee or by the public, allowing some to ignore the guidelines totally and design with no regard to the historic context (Skerry, 2012). Therefore, architects and preservationists have been looking for a way to produce more tangible guidelines by incorporating the physical attributes of the new addition with scientific mathematical equations. This approach is called quantitative evaluation approach.

This paper aims at defining both terms and how the process takes place by reviewing literatures 
that discussed infill design evaluation in the historic environment whether qualitative or quantitative and tries to find and compare the efficiency of both approaches and suggest ways to improve accuracy or enhance the design review process in the field.

\section{Research background}

\section{Contextual Compatibility}

Contextual compatibility has been a hard topic for many years, as the definition of context is still ambiguous despite the numerous researches that try to pin point the main element of the surroundings that make up the context of the site.

Contextuality in architecture refers to the ability of a building to blend seamlessly with its surroundings, forming a relationship with the close neighbors, and the site as a whole by articulating the physical appearance and morphological shape (Sotoudeh, H. and Abdullah, W. M. Z. W, 2013) (Figure 1).
Contextual design is defined as the theory and methodology of delicately and productively integrating new buildings in historic context (Booth, 1989; Loew, 1998). Ukabi (2016) declared that there are a variety of appropriate approaches for the vast types of infill developments in any historical urban environment, focusing on the integration by conforming the physical features (Scale and size) of new buildings to the surroundings. He deduced three methods: Contextual uniformity, contextual continuity and contextual juxtaposition. Contextual uniformity method follows the imitation of the surrounding, not very preferred as it stops the progression of time for this historic site, locking it into a specific timeline, Contextual continuity on the other hand, is not copying the surrounding, instead respecting it while introducing more modern ideas differentiating between the past and the present, Finally contextual juxtaposition shows more of contrasting approach yet doesn't invade the historical core of surrounding context.

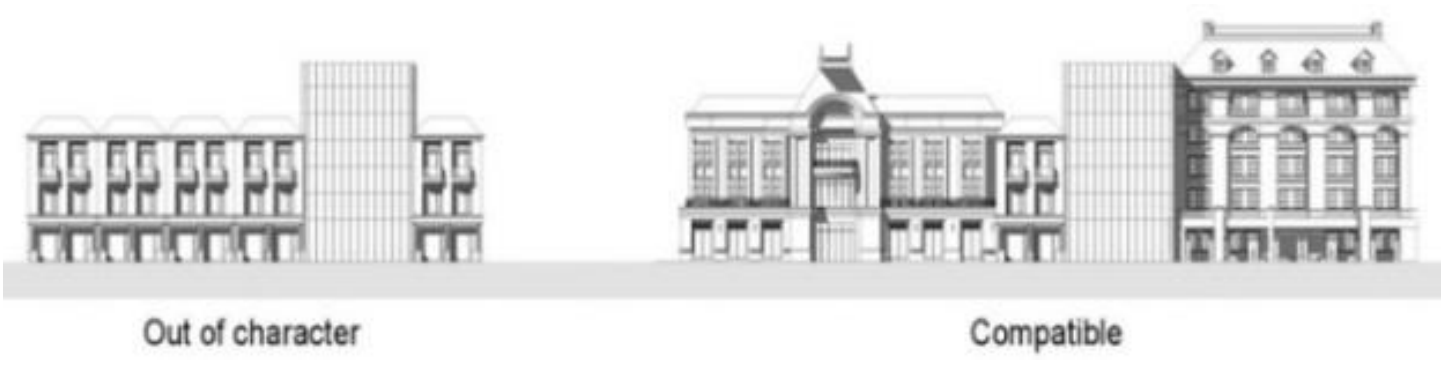

Fig 1. Examples of out-of-character and compatible new buildings on a historic urban setting (Yun Hu et al, 2017).

However generally two common approaches are that has been very popular and common used in the initial design stages and are applied at varying degrees: Replication and Contrast.

Replication is achieved when the new building is related to the urban context by means of imitating or interpreting specific elements that exists within its surrounding, which is the most widely used approach to achieve compatibility.
However as pointed out by Sotoudeh and Abdullah (2012) replication comes into different levels of correspondence: Facsimile, correlation, simile, and metaphor. Day (2015) revealed in an article she published that direct reuse of the old façade usually results in a positive result from the public as proven in her experiment, and this accounts as a high degree of replicability, while another approach was a sophisticated revival of an old building, which is considered a mild level of replicability, and have proven less successful. 


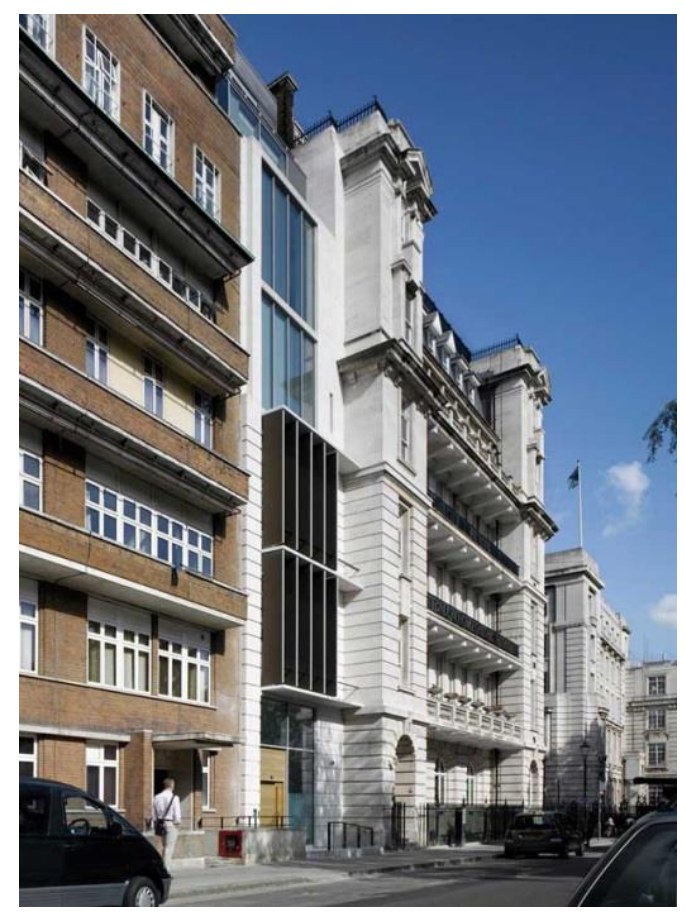

Fig. 2. Shows one of the replication approaches employed (correlation), Clinical Neuroscience Centre, London, (Demiri, 2013).

Contrast approach is identified when coherent building facades are used as a backdrop for the new infill in order for it to stand out (Figure 3). Overby (1980) warned that dealing with contrasting approach is delicate; as if it is used carelessly it can result in disorder and the loss of the sense of place.
Some architects resolve to the contrasting approach as to seem more creative which in fact is sidestepping from the design challenge of creating a compatible design, and then claim they created a relationship through contrast. Yet it is still having a higher appeal to architects compared to replication or achieving harmony.

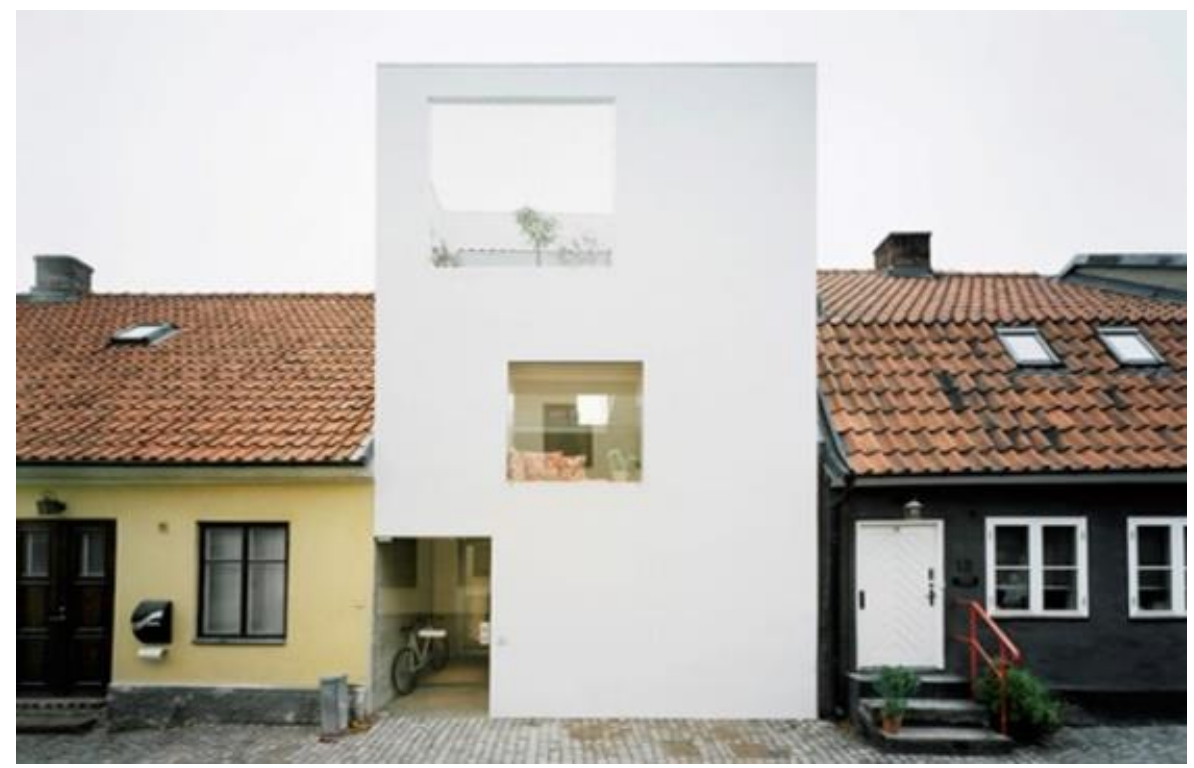

Fig.3. An arrogant contrasting approach, Townhouse, Landskron, (Demiri, 2013). 


\section{Brief History of Intervention Regulations}

There is an extensive policy framework and guidance when it comes to new designs in a historic fabric, as shown in (Figure 4). It all started with the Athens charter in 1931, which was first focusing only on monumental sites (Charter, A., 1931). In 1964 the Venice charter shed light on the importance of maintaining monumental sites to help protect its integrity, developing and setting on some principles (ICOMOS, V. C., 1964). In 1967 the first ICOMOS Symposium was held where the conservation of the urban fabric became one of the major goals. (Horler, M., 1975). In 1972, ICOMOS stated that contemporary architecture in old settings must use materials and techniques of its time (ICOMOS, 1972). In 1975 the Council of Europe declared that an arbitrary design is a threat to the historical context (Council of
Europe, 1975). In 1982 ICOMOS advised the use of traditional techniques while maintaining architectural expression of the current times (ICOMOS, 1982), In (2005) The World heritage documents identified that finding a balance between responding to economic needs and maintaining historic context, and that new intervention should add cultural value, and continuity of the culture (World Heritage Committee, 2005), and in 2011 ICOMOS reinforced the idea of creating an architecture that enhances the compatibility to the context. (ICOMOS, 2011). In (2013) Burra Charter advocated that imitation should be avoided and new design to respect the surroundings, through use of the surrounding scale, bulk, form, character, color, texture, and material, however, it should be readily and easily identifiable referring back to one of the main charters (ICOMOS, A., 2013).

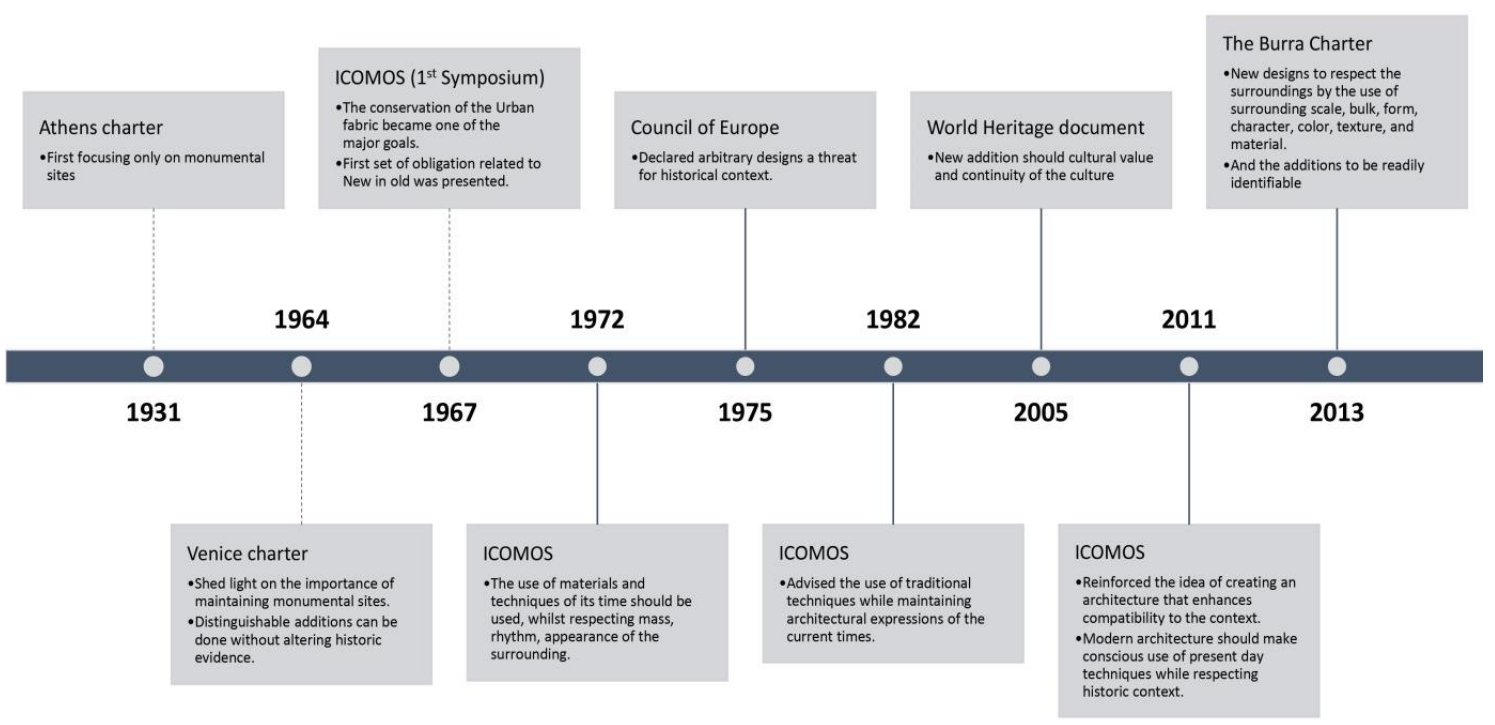

Fig. 4. Timeline of the development of charters of new designs in historic context (Author)

\section{Methodology}

A literature review has been carried out on evaluation methods of new designs in historic development and design guidelines especially the infill designs and the effect on the historic urban context, addressing in specific the differences between the quantitative and qualitative evaluation methods. A total number of (47) literatures have been reviewed in this article, (29) journal articles, (7) books, (8) charters, (3) thesis papers. (Table 1).

\section{Literature Sampling}

The reviewed literatures have all dealt with the notion of new in old, this article focused on infill designs in different locations and different approaches whether qualitative or quantitative, the aim is to evaluate and compare them with each other and figure out which evaluation approach has a more accurate outcome. Out of the (50) articles, (10) are directly related to evaluation of infill designs in historic context, qualitative analysis approach has the most articles published as it has been used for ages and underwent unending improvement to achieve higher accuracy in assessment with around (8) articles. Al-Askary (2016) measured the 


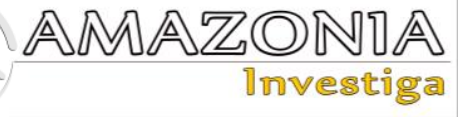

elements that contributed for the visual integration on the level of the part and the whole, while Mohanty and Chani (2015) analyzed a historic district, by first classifying buildings by style, materials, type of uses, and identified the characteristics of the surroundings, and setting eight principles to design in new development. Ukabi (2016) devised an interaction web between owner, community, and designer, and also created a correlation model that identified the relationship between historic and new contexts in a historic urban environment. Soosani (2013) analyzed the free design and compatible designs in historic context and measured the influencing criteria in the old city of Nicosia. Skerry (2012) made an analysis on why and how historicized and contemporary architects, choose a specific design over another, and how they interpret design guidelines. Groat (1983) formulated a framework to act as an assessment for the evaluation of the compatibility of a new building in a historic context. Rahman (1992) integrated design evaluation technique with the design simulation (three-dimensional visualization) to assess the visual impact of the design on the existing urban fabric, and Sotoudeh and Abdullah (2012) analyzed the aesthetic qualities of building elements (formal and symbolic) and their influence on preference from experts' perspective, supported by cognitive calculation tools that were the first approaches for a quantitative integration in the evaluation process. On the other hand, the quantitative approach is more of an interdisciplinary method that relies on mathematical and statistical calculations which would prove to give more tangible results instead of on intuition, and observation surveying, totaling around (2) articles discussed in this paper, $\mathrm{Hu}$, Heath, $\mathrm{Yu}$ Tang, Zhang (2017), assessed the fitness of new designs in historic context with the use of standard deviation approach, while Abu-Obeid, Malkawi, Nassar, and Al-eideh (2009) used prototype theory and feature frequency to know why people prefer infill design over the other, and how the individual's knowledge structure plays a role in it.

Table 1.

Evaluation of Reviewed Literature (author).

\begin{tabular}{|c|c|c|c|}
\hline REFERENCE & $\begin{array}{l}\text { EVALUATION } \\
\text { TECHNIQUE USED }\end{array}$ & $\begin{array}{l}\text { FOCUS OF THE } \\
\text { STUDY }\end{array}$ & $\begin{array}{l}\text { ELEMENTS USED FOR } \\
\text { EVALUATION TECHNIQUE }\end{array}$ \\
\hline $\begin{array}{l}\text { Al-Askary, A. H. } \\
\text { A. (2016) }\end{array}$ & $\begin{array}{l}\text { Qualitative } \\
\text { Questionnaires, } \\
\text { photographs }\end{array}$ & $\begin{array}{l}\text { Visual Properties } \\
\text { (Micro scale) } \\
\text { Visual Properties } \\
\text { (Macro scale) }\end{array}$ & $\begin{array}{l}\text { Façade, Decoration \& detailing, } \\
\text { Building Style } \\
\text { Human scale, Skyline, Building } \\
\text { Harmony and Rhythm }\end{array}$ \\
\hline $\begin{array}{l}\text { Abu-Obeid, N., } \\
\text { Malkawi. F. K., } \\
\text { Nassar, K., Al- } \\
\text { eideh, B. (2009) }\end{array}$ & $\begin{array}{l}\text { Quantitative } \\
\text { Prototype Cognitive } \\
\text { Model, Feature } \\
\text { Frequency }\end{array}$ & Design Variables & $\begin{array}{l}\text { Number of Masses, Proportion } \\
\text { of windows, The form of } \\
\text { windows. }\end{array}$ \\
\hline $\begin{array}{l}\text { Skerry A. D. } \\
\text { (2012) }\end{array}$ & $\begin{array}{l}\text { Qualitative } \\
\text { Questionnaires }\end{array}$ & $\begin{array}{l}\text { Contemporary But } \\
\text { Contextual }\end{array}$ & $\begin{array}{l}\text { Sense of Scale element, } \\
\text { Proportion, Material that took } \\
\text { cues from the surrounding } \\
\text { Use of existing prior knowledge } \\
\text { of history, and indepth research } \\
\text { of historical architectural } \\
\text { precedents }\end{array}$ \\
\hline $\begin{array}{l}\text { Brolin, B. C. } \\
\text { (1980) }\end{array}$ & $\begin{array}{l}\text { Qualitative } \\
\text { Questionnaires, Site } \\
\text { survey, photographs }\end{array}$ & Contextual Design & $\begin{array}{l}\text { Visual Texture, Small scale } \\
\text { details (ornaments Modern and } \\
\text { Traditional) }\end{array}$ \\
\hline Groat, L $(1983,11)$ & $\begin{array}{l}\text { Qualitative } \\
\text { Questionnaire }\end{array}$ & $\begin{array}{l}\text { Contextual Design } \\
\text { Principles }\end{array}$ & $\begin{array}{l}\text { Exterior Site Organization, } \\
\text { Interior Spatial organization, } \\
\text { Exterior Volumetric } \\
\text { composition, Interior Massing, } \\
\text { surface treatment of the planes, } \\
\text { treatment of the interior spaces. }\end{array}$ \\
\hline $\begin{array}{l}\text { Rahman, O. M. A, } \\
\text { (1992) }\end{array}$ & $\begin{array}{l}\text { Questionnaires and three } \\
\text { dimensional }\end{array}$ & On Site Attributes & $\begin{array}{l}\text { Volumetric Composition (Three } \\
\text { dimensional) } \\
\text { Elevation composition ( Two } \\
\text { dimensional) }\end{array}$ \\
\hline & visualization & Off Site Attributes & viewing Conditions \\
\hline
\end{tabular}


Hu, Y., Heath, T., Tang, Y., Zhang, Q. (2017)
Quantitative
Standard Deviation method

Qualitative

Questionnaires

Sotoudeh H., Abdullah W., (2012),

\section{Quantitative}

Standard deviation method

Qualitative

Site survey, photographs, and observation

Qualitative

Ukabi, E.B.(2016)

Soosani, L. (2013)

photographs, observation, surveying
Size

Proportion

Colour

Total Height, Total Width, Segmented Height, Segmented Width, Height \& Width of the openings.

Total Building Façade, Segmented Façade, Proportion of the windows, composition of the openings, horizontal and vertical rhythm of the façade hue, Saturation, Brightness.

Formal Aesthetic (Tangible)

Architectural Aesthetic

Symbol Aesthetic (Intangible)
Spatial Elements

Visual Elements

Visual elements
Massing, Plot ratio, Height, Setbacks.

Orientation, Rhythm,

Proportion, Material \& colour, Scale.

Massing, Siting, height,

Material, Rhytm, and proportions.

\section{Discussion}

Over the past years many people believed that aesthetics is a qualitative, subjective element that simply differs from person to person, and has something to do with a matter of taste. However, as time passed Fechner (1876) proved that aesthetics could be quantified and measured to reveal preference patterns that make a building favorable. This notion was supported by many other types of research that found that certain commonalities in aesthetic preferences gave way for quantifying, and properly measuring what is commonly preferred, which would reduce the clashes between the designers and the community and help produce a more aesthetically pleasing design that conforms to the public values and historic context values (English Heritage,2007).

As shown in Table 1 qualitative and quantitative evaluation techniques; are concerned with measuring building features that affect the urban context: Formal aesthetic and Symbolic aesthetic (Nasar, 1997). Formal aesthetic focuses on the structure of forms (tangible values), while Symbolic aesthetics, is the study of human responses to the forms of the building (intangible values) (Lang, 1988).

\section{Qualitative evaluation of infill design in historic context}

\section{Symbolic Aesthetic}

Humans experience architecture not just through physical elements of the design, Instead, they reflect the individual's internal representation of a building. Symbolic aesthetics is a cognitive process, in which the individual recognizes the content or the style of the structure (denotation), and infers some characters and qualities about it (connotation) (Nasar, 1997). Symbolic aesthetic is determined and influenced by three main elements: Style, Discrepancy, Individual, and Sociocultural differences.

\section{Limitations}

Various limitations exist upon evaluation of a scene or a building starting with the environmental conditions at a specific time, along with an individual's mood that affects their assessment, besides the fact that a change in social class hierarchy showed a clear change in taste and preference. Richer individuals favored more modern approaches than middle-class people who favored typical "traditional" designs (Nasar, 1989), not to mention that as long as taste is subjective, you can't pinpoint what is right, and what is wrong, especially that has been some 


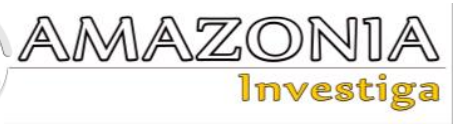

incidents in which initial reaction of a building has changed or reversed over time.

\section{Techniques used and Results}

In Al-Askary's (2016) qualitative evaluation, the survey of locals and users of the area dividing the scales of measurements into microscale and macro scale, the results found showed that in the micro-scale, that ornamentation is a major influence for a high level of visual continuity, and the "color" had the least effect. On the macro scale, the configuration to "human scale factor" had the greater influence of presenting a cohesive historic environment, while "rhythm" scored low on the influence scale. In another research by Soosani (2013) that employed site survey, photographs, map of the city, and observation methods to evaluate five case studies, the evaluation covered two design criteria: spatial elements (massing, siting, height, setback), and visual elements (orientation, rhythm, proportion, material \& color). The results showed that amongst all the case studies evaluated, the most compatible ones shared common criteria which are sitting, scale, and height. Brolin (1980) on the other hand in his book "Architecture in context: fitting new buildings with old" criticized the making of most design criteria's lists that have been used to evaluate the buildings fit. He stated that even if it is perceptive at some points it can be misleading. He further added that there is little influence given to ornamentation as a determinant of fitness and that it is always thought of as traditional electic cornices, instead, the modern ornamentation exists in frameless windows, mullions, cantilevered masses and etc, and the absence of it renders a naked design (Figure 5) Brolin (1980)
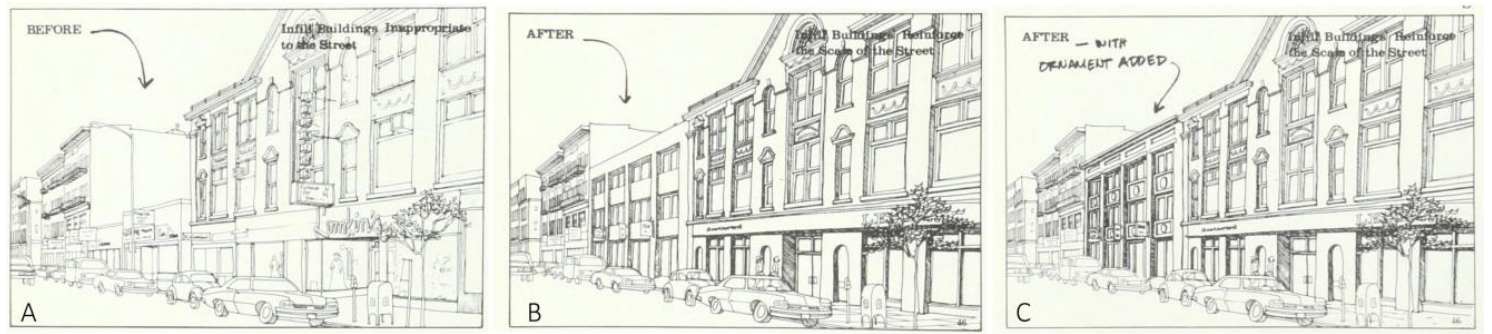

Fig. 5. The three alternatives before and after the analysis results employed, (a) Existing site condition, (b) First proposed design (c)Final mitigation after the analysis, creating a better fit by adding a minor architectural detail Brolin (1980)

Rahman (1992) devised a way to evaluate and simulate the survey/questionnaire results of a specimen project created with the help of threedimensional computer visualization techniques that can help in predicting the visual impact of each element in the design criteria list. As shown in Figure 6, on-site components (site organization, 3d composition, elevational composition), and the off-site components are the variables that will be analyzed and measured in this approach. The visual criteria created have also been made flexible that it can change according to the required influencers in each specific context.

The results of the analysis gave the researcher the strongest contrasting features of the design, with this information in hand the researcher modified them on the computerized model of the design, achieving the perfect "fit" for the historical context. 


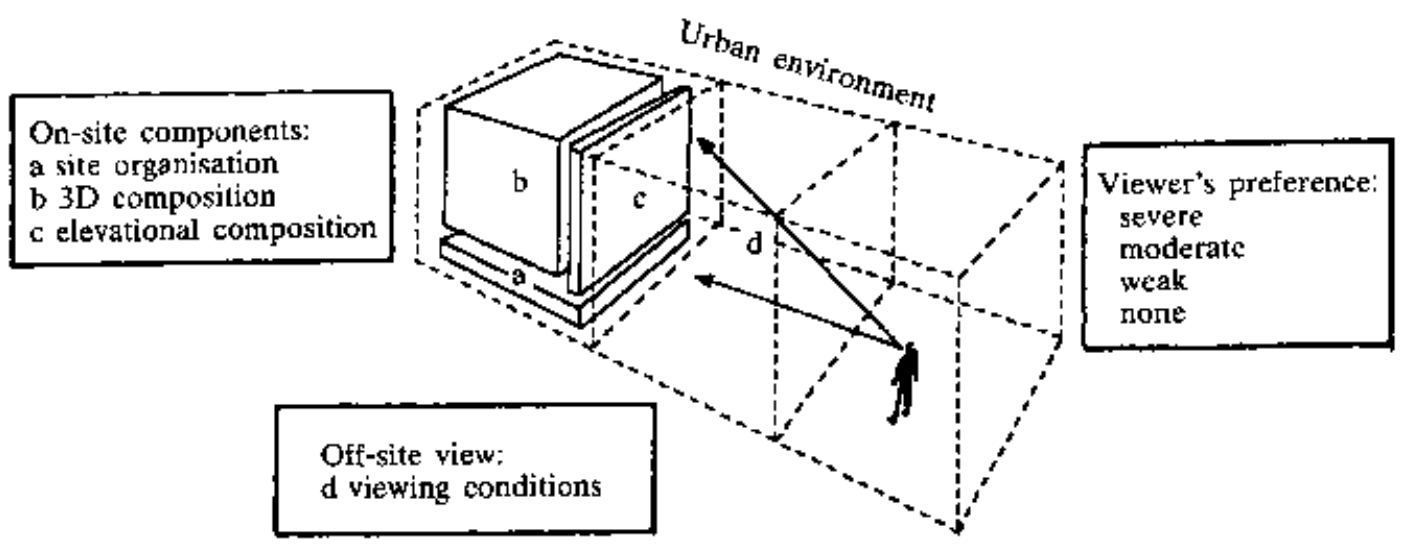

Fig. 6. Analysis of the external physical features of any project in relation to the percipient (Rahman, 1992).

\section{Quantitative evaluation of infill in historic context}

\section{Formal Aesthetic}

As mentioned earlier architectural aesthetics consists of two criteria; formal and symbolic. The formal aesthetic has to do deal with physical features along with relationships such as shapes and proportions, rhythm, scale, degree of complexity color, illumination, and shadowing (Lang, 1987), composition and the system of spatial relation (Groat \& Despres, 1991), and complexity, incongruity, ambiguity, surprise, novelty, and order (Wohlwill, 1976). Groat and Despres (1991) argued that formal architectural properties are evaluated independently from human experience. Several variables stand out when discussing formal aesthetic, and they show the most effect on human response to the built environment. These include complexity, openness, and order.

Why there is a need for a quantitative research approach?

A review of the current literature suggests that quantitative evaluation process is being recommended to help increase the accuracy of qualitative design guidance. The aim of the quantitative evaluation is to examine and evaluate all the information of the building and the evaluators (users) and devise a pattern in preferences. Another reason to approach the evaluation from physical attributes of the building approach is that design control laws that have been established tend to be vague, using terms in the documents that can be interpreted differently from one to another, as it is a set of intangible guidelines. Therefore, an exact and firm foundational aesthetic control needs to be set, in order to create a clear and functional guideline.

\section{Concerns and Limitations}

The above-mentioned variables are very broad and general, leaving so much uncertainty to deduce the true influencer of physical features and different approaches gave different results as will be shown below with the help of scientifically cognitive methods. Moreover, both analysis approaches concentrated on the twodimensional elevations of the case studies, and both the approaches had limited measured variables being evaluated leaving leeway for speculation on whether those alone can influence judgment, not to mention that each historic environment is special and has its own key characteristics. Besides the fact that cognitive mathematical approach is an interdisciplinary method that requires the architect to acquire more knowledge in the field of statistics and cognitive sciences which may render those techniques challenging to understand without sufficient prior knowledge.

\section{Techniques used and results}

\section{Standard Deviation Method (SD)}

In the experiment done by $\mathrm{Hu}$ et al, (2017), they chose a set of variables in order to perform a close detailed analysis on it, size, proportion and color. Size is one of the most common and obvious attributes to be measured as the height and width of the building contribute greatly to the compatibility of the new building with the existing settings, and been mentioned in $90 \%$ of the architecture design controls (Stamps, 1997). An appropriate proportion in a historical setting reflects the architectural principles of that particular historic period (Punter, 1999:132). 


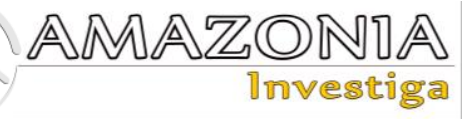

Color is an essential element in the physical environment, where color is a reflection of architectural culture and is one of the first things that are perceived besides the form of the building.

In the research the size, proportion, and color measurement were quite meticulous, first, a set of size and proportion are being measured from the new addition and the surrounding as shown in (Figure 8), in term of size; total height, and width of the building, segmented height, and width of the building, and the height and width of the opening. While for the proportion 4 indicators were taken into consideration; the proportion of the total building façade and the segmented façade, proportion of the windows, composition of the openings in the main façade. And in terms of color analysis, three attributes are analyzed: hue, saturation, and brightness (HSB).

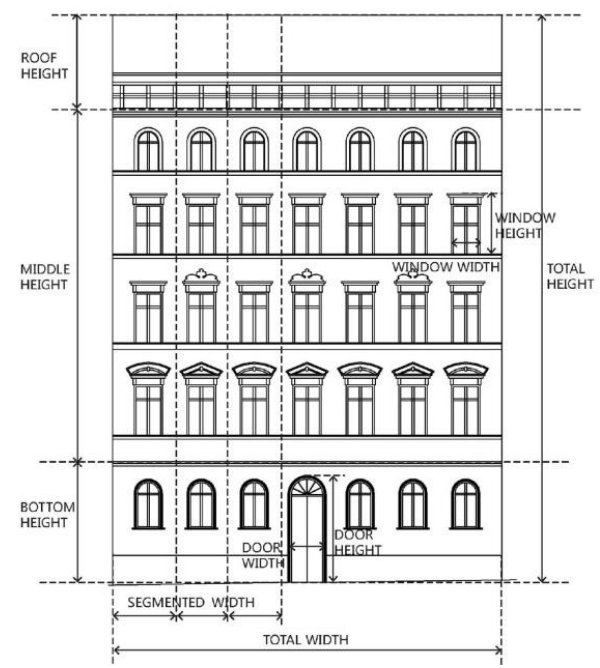

Fig. 7. Diagram of the varying set of data collected from a building in for size and proportion measurments. (Hu, et al, 2017)

Colors for the most part are expressed by RGB and HSB. The HSB is used to identify the abstracting color from the facades. As there might be a façade with multiple colors only two are analyzed the main color and the sub color, moreover, color composition was also an important factor in the study of the façade. Color composition refers to the ratio of different colors used in the architectural façade. The ratio of colors is identified into three types: Main color, a secondary color, embellishment color, the Main color was a dominant color of the building, the secondary was any color used at a lesser degree, while, the embellishment color was that of the door, windows, and ornamental elements.

The collected data is analyzed with the Standard deviation method (SD) (Figure 9), "standard deviation is a measure of the amount of variation or dispersion of a set of volumes (Bland, 1996)" (Hu, et al, 2017). A low standard deviation implies that the volume is nearest to the mean of the set, while a high standard deviation implies that the values are stretched over a wide range. Therefore, SD was used to evaluate the variation introduced by the new infill design in a historic context. It showed that if the new proposed addition made the SD larger, that would indicate there is an increase in the fluctuation of data.

On the other hand if it showed a smaller SD that indicates the new design lessened the fluctuations of the data (Hu, et al, 2017). In SD analyses if the inharmonious features are implemented the original data set will fluctuate greatly, while if harmonious features are introduced, calmer results are obtained. Normal distribution is used to anticipate credible intervals and figure out the degree of compatibility between new and old, about $68 \%$ of values are within one SD away from the mean, and about $95 \%$ of the values lie within 2 SDs and almost a $100 \%$ are within three SDs. It is therefore relatively easy to calculate the valid intervals of data set to serve the evaluation criteria. 


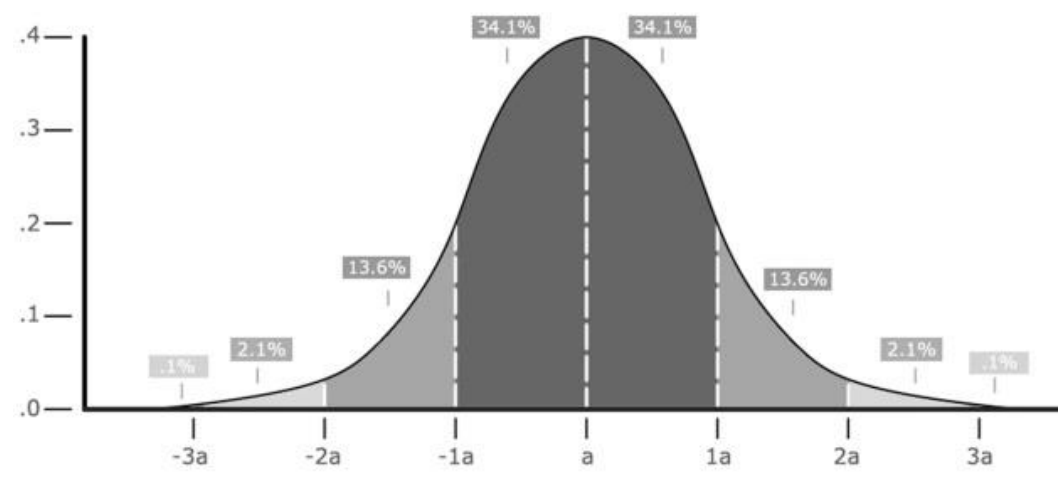

Fig. 8. Normal distribution diagram (SD) (hu, y. et al, 2017)

The results that was accumulated showed that windows and rhythm played a major part in achieving harmony with the surrounding and that even that sometimes the infill design is showing apparent contrasting style to the surroundings. This evaluation process can actually find out whether it is compatible or not.

\section{Prototype Approach and Feature Frequency Approach}

In this research Abu-Obeid, Malkawi, Nassar, and Al-edih (2009) made an experiment using two cognitive analysis approaches, the first is "Feature Analysis Approach", which proposes that in order to recognize the pattern, decomposition of the whole pattern is done into constituent features, and those features are compared with the stored ones, while the other analysis approach is Template matching, which analyzes unknown patterns as a unique whole and identifies it based on its overlap with various standards (Reed, 1978: 139).

The fundamental concept of prototype theory is that a variety of patterns from the general knowledge creates experiences that vary in consistency with the knowledge structure. Which means that examples that match the knowledge structure are identified as a typical knowledge structure and eventually due to their familiarity they were termed "good examples" (Rosch and Mervis, 1975; Purcell, 1984, 1986).

The study was set to create and manipulate design variables and create a number of artificial architectural patterns. Those architectural patterns were introduced as street façade examples, which were constructed from previously identified patterns, then those façades were to be used as a reference learning pattern, as in the next step a subgroup of architectural patterns was to be employed from the reference patterns developed earlier, in order to present the newly created pattern as a possible infill to the street façade. A prototype pattern had to be identified for each street façade, the prototype of the street façade is the pattern which has the least discrepancy from all other patterns in the façade. Prototype theory contends that the fit of any infill pattern with the sample façade layout will be measured based on the dissimilarity from the prototype of the façade. In addition to this, the prototype has a number of shared features with the existing façade sample (feature frequency). The feature frequency theory suggests that any created pattern is evaluated in its fit with the context, according to its accumulated number of shared patterns with all patterns of the street façade (feature frequency) (Abu Obeid, et al. ,2009).

The study covered three variables only due to the limitations of dealing with multiple variables, 1) the number of masses (two possibilities), 2) the proportion of the masses (two possibilities), 3) the form of the windows (nine possibilities), totaling of thirty-six alternatives created. The experiment consisted of creating a different set of street façades, each containing 5 design variations, and the participants were presented with one reference from each group and were asked to rank it in level of fitness with all the fifteen street façade, where the highest represented the highest contextual.

The results showed that either distance from prototype or feature frequency regarded for a considerable part of the participant's choice of the best contextual fit for the infill patterns. The prototype approach showed that the more the infill patterns were more secluded from the prototype the less it was assessed as belonging to the context. In the case of the feature frequency approach, the more features shared with the context, the more they were evaluated as fitted to the context. It shows that the participant's knowledge structure was not referenced to the 


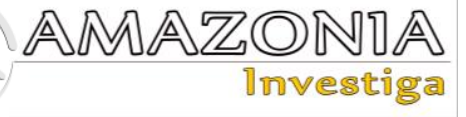

architectural context provided. They seem to have attained general information about all the groups during the experiment, and this notion of general information appears to be noticed in both group's prototype and feature frequency.

\section{Conclusions}

As mentioned in previous sectors both approaches showed promising results, starting with the qualitative evaluation technique, the results that were outputted in the several works of literature reviewed showed that this method provided a better alternative for some of the proposed designs, and the surveyed participants supported these improvements. As mentioned before in the limitations, a limited group was surveyed and potential result differences can be noticed, which would result in a different outcome, however, the qualitative approach is still the only approach that is being used in the evaluation and design review process and most of the current design guidelines still rely on it as shown by the use of intangible vague terms. With the development of technology, the field is digitizing the process with aims of simplifying the design stage and provide more alternative in shorter time spans in order to evaluate and improve the three-dimensional proposals faster and getting more instantaneous results from their evaluations, however, a digitized process of evaluation should also be considered to avoid the intentional disregard of the guidelines which result into a design that is hated by the public.

On the other hand, the quantitative approach relied more on numbers, and math than people's feedback. It proved functional and reliable when experimented within the case study. Further on, the quantitative methods focused on the question of why and how people make decisions the way they do and how they prefer a sample over the other. In an effort to design something that is preferred by everyone, still, this interdisciplinary field is rather new and requires a lot of knowledge and time for architects to start working by it and many more experiments to prove its efficiency. Besides trying to include this process into a more volumetric approach instead of the existing two-dimensional evaluation assessment. However, in the meantime, a better result can be achieved by merging the two technique together, as the qualitative method will try to point out the essential visual impacts (as it will be a faster approach than the prototype or the feature frequency approach) that can be then measured by the standard deviation method that will be able to better measure proportionally the link and harmony with the surroundings.
To conclude, as stated by Brolin (1980) "The Longer one studies the question of fitting new architecture with old, the more demanding one becomes". The general results showed that to achieve a visual fit by satisfying some of the above-mentioned criteria like Massing, Size, Proportion, Ornamentation and etc., a good relationship can be accomplished. It will be suggested that further experimentation to be done on several case studies of replicated and contrasting infill to further test the efficiency of the system and to start a step by step integration of behavioral sciences especially cognitive sciences into the field of architecture as it has a profound effect on helping architects understand how people perceive, reason, and interact with their surroundings. Therefore, it will give the architects a better way to design with their own style while conforming to the needs of the public, therefore will help develop the evaluation techniques in the future.

\section{References}

Abu-Obeid, N., Malkawi, F.K., Nassar, K., \& Al-eideh, B. (2009). Cognitive Mathematical Approaches for Evaluating Architectural Contextual Fit. Nexus Network Journal, 11(2), pp 163-182.

Al-Askary A. H. A. A., Al-kaissi A. O. H. (2016). Visual Integrations of Historic Cities Centers Al Rashed Street. Center of Urban and Regional Planning. University of Baghdad. 12(1), pp 81-107

Bland, J. M., \& Altman, D. G. (1996). Statistics notes: measurement error proportional to the mean. Bmj, 313(7049), pp. 106.

Booth, Ph. (1989). The rule, discretion, and local responsibility: Development control case studies in the urban community of Lyon (Doctoral Dissertation), University of Sheffield.

Brolin, B. C. (1980). Architecture in Context: Fitting New Buildings with Old. New York: Van Nostrand ReinholdCompany.

Bulimbašić, S. (2008). In the service of heritage, Conversation. Kvartal: Crónica de la historia del arte croata, vol. V (4), pp. 22-32

Charter, A. (1931). The Athens Charter for the restoration of historic monuments. In Ist International Congress of Architects and Technicians of Historic Monuments, Athens, October.

Council of Europe (1975). The Declaration of Amsterdam, Congress on the European Architectural Heritage. Amsterdam.

Davies, M, (2003). Design in the Historic Environment. Building and Environment, Recovered 
http://www.buildingconservation.com/articles/d esign/design.htm

Day, L. L. (1992). Placemaking by Design. Environment and Behavior, 24(3), pp 326-346. doi:10.1177/0013916592243003

Demiri K. (2013). New Architecture as Infill in Historical Context. Architectural and Urban Planning, 5, pg 44-50, doi: 10.7250/ aup 2015. English Heritage (2007). Conservation principles policies and guidance for the sustainable management of the historic environment. English Heritage, 30-33.

Fechner, G. T. (1876). Vorschule der Asthetik. Leipzig. Germany: Breitopf \& Hartel, Recovered from:

https://archive.org/details/vorschulederaest12fec huoft/page/n229/mode/2up.

Gharehbaglou, M., Nejadebrahimi, A., Ardabilchi, I. (2019). Infill Architecture: An Interdisciplinary Approach to the Design of Historic Context Case Study: Mashruteh Complex in the Historic Bazaar of Tabriz, Iran. Revista científica de Bagh-e Nazar, 16(76), pp. 57-68.

Groat, L. (1983). Measuring the fit of new to old. Architecture, New York: Cambridge University Press. November, 58-61.

Groat, L. N., \& Despres, C. (1991). The significance of architectural theory for environmental design research. In E. H. Zube \& G. T. Moore (Ed.), Advances in environment, behavior, and design (Vol. 3, p. 3-53). New York: Plenum.

Horler, M. (1975). Modern architecture and Ancient monuments. Monumentum, 11,7-25.

Hu, Y., Heath, T., Tung, Y., \& Zhang, Q. (2017). Using Quantitative Analysis to Assess the Appropriateness of Infill Buildings in Historic Settings. Jorunal of Architectural and Planing Research, 34(2).

ICOMOS 1972. Resolutions of the Symposium on the introduction of contemporary architecture into ancient groups of buildings, at the 3rd ICOMOS General Assembly, Budapest. [online 17.07.2018] Recovered from https://www.icomos.org/en/chartersandtexts/180-articles-en-francais/chartes-etnormes/383-resolutions-of-the-symposium-onthe-introduction-ofcontemporary-architectureinto-ancient-groups-of-buildings-at-the-3rdicomos-general-assembly

ICOMOS, A. (2013). The Burra Charter: The Australia ICOMOS charter for places of cultural significance. Australia ICOMOS Incorporated. ICOMOS, F. C. F. (1982). Economic and financial aspects of the conservation of monuments and historic city centres. Availabe: https://www.icomos.org/en/368whp/cultural/3049-1982
ICOMOS, U. (2011). The Valetta Principles for the Safeguarding and Management of Historic Cities, Towns and Urban Areas. 7th ICOMOS General Assembly.

ICOMOS, V. C. (1964). International Charter for the Conservation and Restoration of Monuments and Sites-Developed at the 2nd International Congress of Architects and Technicians of Historic Monuments. Venice, Italy.

Lang, J. (1987). Creating architectural theory: The role of the behavioral sciences in environmental design. New York: Van Nostrand Reinhold.

Lang, J. (1988). Symbolic aesthetics in architecture: Toward a research agenda. In J. L. Nasar (Ed.), Environmental aesthetics: Theory, research, and applications, New York: Cambridge University Press, 11-26.

Loew, S. (1998). Modern architecture in historic cities: Policy, planning and building in contemporary France. London: Routledge. http://dx.doi.org/10.4324/9780203380222.

Mohanty, R. N., Chani, P. S. (2015). Infill Design in the Historic Precinct of Haridwar, Journal of Civil Engineering and Environmental Technology, 2(3), pp 265-270.

Mokhovikov, S., Alekseenko, L., Knyazeva, M., Murog, I., \& Larina, O. (2019). Studies of cultural heritage sites of federal significance. Amazonia Investiga, 8(21), pp 296-306. https://amazoniainvestiga.info/index.php/amazo nia/article/view/106

Nasar, J. L. (1989). Perception, cognition, and evaluation of urban places. In Public places and spaces (pp. 31-56). Springer, Boston: MA.

Nasar, J. L. (1997). New developments in aesthetics for urban design. In Toward the integration of theory, methods, research, and utilization (pp. 149-193). Springer, Boston: MA. Navickiene, E. (2012). Infill Architecture: Chasing Changes of Attitudes in Conservation of Urban Heritage. In HERITAGE 2012 proceedings of the $3^{\text {rd }}$ international conference on Heritage and Sustainable Development, Lithuania, Vol. 2, p. 1325-1334.

Overby, O. R. (1980). Old and New Architecture: A History. Washington D.C: the preservation press, 12, 18-36, Recovered from: https://archive.org/stream/oldnewarchitectu0000 unse?ref=ol\#page/20

Punter, J. (1999). Design guidelines in American cities: A review of design policies and guidance in five west coast cities (Vol.2). Liverpool: Liverpool University Press.

Purcell, A. T. (1984). Multivariate models and the attributes of the experience of the built environment. Environment and Planning B: Planning and Design, 11(2), 193-212. 


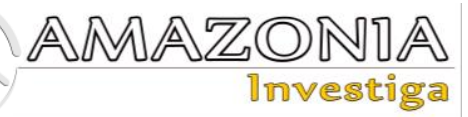

Purcell, A. T. (1986). Environmental perception and affect: A schema discrepancy model. Environment and Behavior, 18(1), 3-30.

Rahman, O. M. A., (1992). Visual quality and response assessment: an experimental technique. Environment and Planning B: Planning and Design, 19(6), pp. 689-708. doi:10.1068/b190689.

Reed, S. (1978). Schemes and theories of pattern recognition. In Cartrette, E. C., x(Ed.), Handbook of Perception (p. 139-162). Vol. 9. New York: Academic Press.

Rosch, E., and Mervis, C. B. (1975). Family resemblances: Studies in the internal structure of categories. Cognitive Psychology, 7(4), 573-605. Skerry, A. D. (2012). Interpreting the standards: design professional and historicized design (Master's Thesis). Roger Williams University, Bristol.

Soosani, L. (2013). Questioning the compatibility of the infill architecture in historic environment, case study: walled city of Nicosia (Doctoral dissertation) Institute of graduate studies and research, urban design, Eastern Mediterranean University, Famagusta.

Sotoudeh, H., and Abdullah, W. M. Z. W. (2012). Affected variables on successful infill design in urban historic context. Art and Design Studies, 3(9), pp. 7-12.

Sotoudeh, H., and Abdullah, W. M. Z. W. (2013). Contextual preferences of experts and residents: issue of replication and differentiation for new infill design in urban historical context. World Applied Sciences Journal 21(9), pp. 1276-1282.

Stamps, A. E. (1997) A paradigm for distinguishing significant from non-significant visual impacts: theory, implementation, case histories. Environmental Impact Assessment Review, 17(4), 249-293.

Ukabi, E. B. (2016). Harnessing the Tension from Context-duality in Historic Urban Environment. Journal of Sustainable Development, 9(1), p 77.

Vozbinaite, G. K. (2015). New Forms in Historic Urban Environment: Regeneration of Vilnius Old Town (Master's Dissertation), Department of Architecture, University of Strathclyde, Glasgow. Recovered from: https://issuu.com/guoste/docs/new_forms_in_hi storic_urban_environ.

Wohlwill, J. F. (1976). Environmental aesthetics: The environment as a source of affect. In I. Altman and J. F. Wohlwill (Ed.), Human behavior and the environment: Advances in theory and research (Vol. 1, pp. 37-86). New York: Plenum.

World Heritage committee (2005). Decisions of the $29^{\text {th }}$ session of the World Heritage Committee. For the convention concerning the protection of the world cultural and natural heritage. Symposium led by UNESCO, Durban. 